Научная статья

https://doi.org/10.22455/2541-7894-2021-10-100-134

УДК 821.111
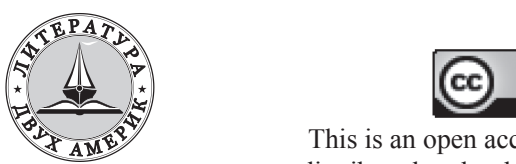

This is an open access article distributed under the Creative

Commons Attribution 4.0 International (CC BY 4.0)

\title{
ОЛЬГа КАРАСИК-АПДАЙК
}

\section{СОВРЕМЕННАЯ ЕВРЕЙСКАЯ ПРОЗА США}

Аннотация: В статье представлен обзор американской еврейской прозы второй половины XX - первых двух десятилетий XXI века в контексте мультикультурной литературы США. Определение еврейской литературы всегда являлось предметом споров. Автор статьи, опираясь на мнения критиков, приходит к выводу, что критерием отнесения того или иного писателя к еврейской литературе является художественное воплощение собственного еврейского опыта и идентичности в его произведениях, взгляд «изнутри», с точки зрения коллективной памяти и сопричастности истории и культуре. Еврейская литература - один из наиболее развитых этнических компонентов мультикультурной литературы США. Писатели, чье творчество рассматривается в данной статье, признаны во всем мире, их произведения переведены на многие языки, в том числе русский, известны читателям и являются предметом изучения литературоведов. Сегодня американская еврейская литература представлена двумя поколениями писателей. «Старшее» - авторы, родившиеся в 1920-1930-е гг. и начавшие писательскую карьеру в 1960-е, когда происходила смена поколений в национальной литературе. К «молодому» поколению автор статьи относит писателей, которые начали литературную карьеру в 2000-е гг. На примере творчества наиболее известных авторов двух поколений рассматриваются факторы, определяющие самобытность американской еврейской литературы, и характерные для нее темы, проблемы, мотивы: поиски идентичности и собственных корней, художественное осмысление трагедии Холокоста, этнические стереотипы, образ еврейской семьи, традиции еврейского юмора. Изучение творчества современных еврейских писателей США позволяет делать выводы о художественном отображении бордерного сознания, национальной и этнической идентичности, коллективной памяти.

Ключевые слова: американская еврейская литература, мультикультурализм, идентичность, коллективная память, религия, стереотип.

Информация об авторе: Ольга Борисовна Карасик-Апдайк, доктор филологических наук, доцент, профессор, кафедра русской и зарубежной литературы, Казанский федеральный университет, ул. Кремлевская, д. 18, 420008 г. Казань, Россия. ORCID ID: 00000001-7265-4896. E-mail: karassik1@yandex.ru

Для цитирования: Карасик-Апдайк О.Б. Современная еврейская проза США // Литература двух Америк. 2021. № 10. С. 100-134.

https://doi.org/10.22455/2541-7894-2021-10-100-134 

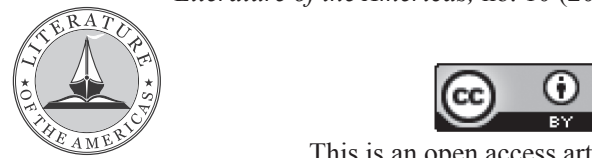

Research Article

https://doi.org/10.22455/2541-7894-2021-10-100-134

UDC 821.111

This is an open access article distributed under the Creative

Commons Attribution 4.0

International (CC BY 4.0)

\section{Olga KARASIK-UPDIKE}

\section{CONTEMPORARY JEWISH PROSE IN THE USA}

Abstract: The essay presents an overview of Jewish American prose of the second half of the $20^{\text {th }}$ - first two decades of the $21^{\text {st }}$ century within the context of multicultural literature of the USA. The definition of Jewish literature remains a matter of debate. The author of the essay based on the opinions of critics concludes on the criterion for assigning a writer to Jewish literature. It is the artistic embodiment of the personal Jewish experience and identity in the works of literature, the view "from inside," the perspective of collective memory and the connection to history and culture. Jewish literature today is one of the most developed ethnic segments of multicultural American literature. Writers under study are recognized throughout the world, their works have been translated into many languages, including Russian, they are known to readers and have already become the subject of study by literary scholars. Today, Jewish American literature is represented by two generations of writers. "Senior" generation includes the authors born in the $1920 \mathrm{~s}-30 \mathrm{~s}$ who began their literary careers in the $60 \mathrm{~s}$ when there was a generational change in national literature. "Young" generation is represented by the writers who began their literary careers in the 2000s. On the example of the works of the most famous authors of both generations, the author of the essay talks about the factors determining the specific features of Jewish American prose and its characteristic themes, problems, and motives: the search for identity and roots, the representation and rethinking of the Holocaust, ethnic stereotypes, the image of the Jewish family, and the traditions of Jewish humor. The study of the works of modern Jewish writers in the United States allows us to draw conclusions about the display of border consciousness, national and ethnic identity, and collective memory in fiction.

Keywords: Jewish American Literature, Multiculturalism, identity, collective memory, religion, stereotype.

Information about the author: Olga B. Karasik-Updike, Doctor Hab. in Philology, professor, Department of Russian and World Literature, Kazan Federal University, ul. Kremlevskaia 18, 420008 Kazan, Russia. E-mail: karassik1@yandex.ru

For citation: Karasik-Updike, Olga. "Contemporary Jewish Prose in the USA." Literature of the Americas, no. 10 (2021): 100-134. https://doi.org/10.22455/2541-7894-2021-10-100-134 
Одним из наиболее удачных вариантов развития еврейской культуры, несомненно, является культура евреев в США, достигшая своего расцвета в XX столетии. С начала своего существования США обеспечили евреям те свободы, которых они не имели в других странах, веками оставаясь преследуемым меньшинством: возможность выбора места проживания, сферы деятельности, образования и в то же время свободу вероисповедания и соблюдения обрядов без страха за собственную жизнь. Заявляя в своей конституции о равенстве, свободе и возможностях для всех граждан, США стали для евреев второй Землей Обетованной. И хотя американское общество, как любое другое, не было полностью свободно от антисемитизма, все же евреи чувствовали себя там в большей безопасности, чем в Европе, и, в частности, в Российской империи. Это стало причиной их массовой эмиграции. По различным данным от двух до трех миллионов евреев эмигрировали в США из России на рубеже XIX-XX столетий. Они внесли значительный вклад в развитие страны.

Особое внимание, которое протестантизм уделял Ветхому Завету - священным книгам, общим для иудаизма и христианства, также стало благоприятным фактором, который, вкупе со свободой совести и вероисповедания, предоставленной евреям наравне со всеми другими гражданами США, также способствовал интеграции и небывалому подъему еврейской культуры в Новом Свете. Уже в ХХ столетии наравне с возможностью открыто исповедовать иудаизм евреи в США осознали и возможность существования различных вариантов религиозности и ее выражения. Они смогли причислять себя к неортодоксальным ветвям иудаизма, которые получили распространение именно в Америке (например, так называемый прогрессивный иудаизм, или реформизм, в котором строгие иудейские законы адаптируются к современным реалиям), или полностью отойти от религии, не порывая при этом с еврейством и культурной памятью. Это отмечается в предисловии Э.М. Бадик к сборнику статей, посвященных сравнению американской и израильской литературы: «...хотя создание государства Израиль в 1948 году спровоцировало главный сдвиг в еврейском мировоззрении, который наиболее серьезно отразился на еврейской литературе, все же вполне вероятно, что с точки зрения самоопределения евреев эмиграция в Соединенные Штаты была не менее значима. Просвещение с его верой в разум как контролирующий фактор человеческой истории и эволюции культуры позволило евреям выйти из штетлов и отойти от традиций ортодоксального иудаизма, а значит, дало возможность 
представить свою жизнь в другом, светском варианте, в иных национальных рамках» ${ }^{1}$ [Budick 2001: 3]. В Америке стало возможно то, что было неприемлемым для еврея в любой другой части мира, - свобода самовыражения и выбора образа жизни․

Важным фактором для развития еврейской культуры в целом и литературы в частности оказалось и то, что евреям, проживавшим в США, удалось избежать Холокоста. Они не были его жертвами, хотя трагедия стала определяющим фактором коллективной исторической памяти и для американских евреев, как и для европейских.

Сегодня еврейская культура занимает серьезное место в национальной культуре США, что очевидно даже на бытовом уровне. Кафе и магазины мегаполисов украшают атрибутами иудаизма к празднику Хануки; большинство американцев знают, что такое бар- и бат-мицва, и независимо от своего вероисповедания, посещали эти празднования у своих друзей и одноклассников; школы Нью-Йорка и других крупных городов объявляют неучебным днем Йом Кипур - иудейский Судный день и т. д.

Еврейская литература сегодня является органичной частью мультикультурной литературы США. «Антология американской еврейской литературы» издательства Norton, вышедшая в 2000 г., начинается с текстов, созданных в XVII в., то есть в колониальный период, - писем, заметок, проповедей и других публицистических произведений. Далее приводятся художественные произведения, поэзия и показывается развитие еврейской литературы на протяжении всей истории существования США до XXI столетия и ныне живущих авторов. Антология охватывает все роды, виды и жанры литературы, причем создававшиеся не только на английском языке: она включает и переводы с идиша и иврита.

В предисловии редакторы антологии рассуждают о том, на какое место поставить определение национальной, а на какое - этнической принадлежности: «еврейская американская» или «американская ев-

1 Здесь и далее перевод с англ. наш. - O. К.-A.

2 Здесь весьма характерны примеры из массовой культуры. Так, фильм «Секс в большом городе 2» (2010) открывается сценой еврейской свадьбы двух мужчин. Иудаизм категорически запрещает гомосексуализм, и брачная церемония, хупа, для однополой пары является нонсенсом. Однако в США с разрешением официальных браков однополых пар и распространением прогрессивного иудаизма это стало вполне возможным и весьма распространенным явлением, не вызывающим удивления сегодня. 
рейская» литература, подчеркивая, что оба варианта верны. Они также говорят о дискуссионности критериев отнесения того или иного автора к еврейской литературе, приводя мнения авторитетных литературоведов, среди которых Лесли Фидлер и Гарольд Блум, известные критики и ученые, писавшие, в том числе, и о еврейских авторах США. «В конце концов, еврейская американская литература может так или иначе вытекать из самоидентификации автора как еврея. Однако это самое упрощенное определение вновь поднимает важнейший вопрос - об идентичности» [Chametzky et al. 2000: 3].

Именно идентичность стала критерием, по которому мы относим авторов к современной американской еврейской литературе. В основном мы говорим о писателях, которые родились в США или же живут там с детства, их родным языком является английский, и именно на нем они создают свои произведения. Часто они не владеют ни одним из еврейских языков. Некоторые заявляют о своем атеизме, полностью отрицая связь с иудаизмом. С одной стороны, их творчество помещается в рамках этнической еврейской литературы и является частью национальной мультикультурной литературной традиции США. С другой стороны, оно принадлежит мировой еврейской литературе, так как для нее не характерно единство языка, авторы происходят из разных стран, принадлежат к разным национальным культурам и имеют мало общего между собой. Их читательские аудитории часто различны и могут не пересекаться. Фактически, идентификация себя как еврея и наличие общей исторической памяти, - единственное, что может объединить таких, например, писателей, как Дина Рубина (уроженка СССР, израильтянка, пишущая на русском языке), Давид Гроссман (известный современный ивритоязычный израильский писатель), Филип Рот (американец, писавший только по-английски) и Авром Суцкевер (один из крупнейших еврейских поэтов XX столетия, писавших на идише). Еще более далекими от вышеперечисленных известных и в нашей стране авторов окажутся писатели, представляющие еврейские литературы Марокко, Йемена и т. п.

Специфика еврейской литературы США состоит в том, что в XX столетии, особенно в его второй половине, она преодолела сложившийся образ «литературы меньшинства», о котором говорит известный российский специалист по литературе на идише Валерий Дымшиц: «Образ еврейской литературы связан в основном с классиками XIX века, а если быть совсем честным, то с замечательным во всех отношениях писателем, но одним - Шолом-Алейхемом. <..> 
Еврейская литература совершенно не попадает в обойму великих литератур XX века, передовых» [Вольтская 2012]. Сегодня мы видим, что именно американская еврейская литература не только во многом стала представлять национальную литературу США, но и вышла на высочайший мировой уровень, дав двух нобелевских лауреатов - Исаака Башевиса-Зингера и Сола Беллоу — и целый ряд других громких имен, в том числе и представителей молодого поколения, пришедшего в литературу уже в начале нового тысячелетия.

В своем сборнике эссе «Говорящая лошадь. Бернард Маламуд о жизни и творчестве», вышедшем в 1972 г., один из наиболее знаменитых американских еврейских авторов рассуждает: «Я не уверен, что можно говорить о некой еврейской “школе” в современной американской литературе. Очевидно, что есть довольно много американских еврейских писателей, чьи предки происходят из разных стран. Они в известной степени имеют общий еврейский опыт и воплощают его в своих произведениях. Вернее, у них есть то, что можно назвать эмоциональным воплощением этого еврейского опыта, сформированного после того, что произошло в Германии, когда она была под властью Гитлера. Вероятно также, что они имеют общие этнические (еврейские) интересы. И возможно, есть нечто общее в их писательской манере и стиле, которые сосредоточены вокруг “обработки" человеческого материала. Но кроме этого, я не нахожу ничего, что можно назвать общей идеологией. Мы говорим о совершенно разнородной группе писателей, среди которых Сэлинджер, Мейлер, Рот, Беллоу, Стерн, Блехман, Маркфилд. Может быть, они влияют на творчество друг друга, может быть, нет. Они все очень разные, у них почти нет ничего общего. Кто-то из них ведет еврейский образ жизни и соблюдает традиции; кто-то смотрит на все это сквозь пальцы и тем не менее имеет причины называть себя евреем. Я бы сказал, есть некая группа американских еврейских писателей, разрабатывающих в основном американские темы, и иногда касающихся еврейских вопросов. А порой и это отсутствует, как, например, в случае с Мейлером, Сэлинджером и некоторыми отдельными произведениями других евреев...» [Malamud 1996: 136].

На момент выхода книги, вероятно, можно было вполне согласиться с маламудовским определением американской еврейской литературы скорее как «группы писателей», чем как полноценного еврейского этнического компонента мультикультурной литературы США. Однако по прошествии почти полувека со времени написания этих строк мы наблюдаем, как изменилась ситуация, чему немало спо- 
собствовало и творчество самого Маламуда: сегодня мы говорим об американской еврейской литературе как о полноценном и самобытном феномене, развитие которого можно проследить на протяжении уже нескольких десятилетий, что дает нам возможность выявить некоторые закономерности его функционирования.

В конце XX - начале XXI в. еврейская литература США представлена двумя поколениями авторов. Те, кого мы относим к старшему поколению, родились в 20-30-е гг. ХХ в. и начали писать в 50-60-е, когда в американской литературе происходила смена поколений. В те же годы на литературной сцене стали знамениты имена еще более старших авторов - Беллоу (1915-2005) и Маламуда (1914-1986), которые во многом определили развитие современной еврейской прозы. Среди тех, кто начал свой творческий путь в 60-е, выделяется Филип Рот (Philip Roth, 1933-2018) как наиболее выдающийся и знаковый автор. Его творчество вышло далеко за пределы круга еврейской прозы, и он по праву является одним из наиболее значимых американских авторов второй половины XX в. К тому же поколению относится Вуди Аллен (Woody Allen, p. 1935), известный не только как режиссер и актер, но и как автор рассказов и пьес, явно отражающих еврейскую специфику.

Писательницы Грейс Пейли (Grace Paley, 1922-2007) и Синтия Озик (Cynthia Ozick, p. 1928) известны своей малой прозой, а Озик является еще и одним из наиболее авторитетных литературных критиков. Ей принадлежат известные статьи о творчестве Франца Кафки, Исаака Бабеля, о дневнике Анны Франк и т. д. К тому же поколению мы относим и Джозефа Хеллера (Joseph Heller, 1923-1999), знаменитого американского писателя, прославившегося в 1960-е благодаря роману «Поправка-22», в котором, однако, никак не отражается еврейская специфика. Мы же обращаемся к другим его произведениям.

Важную роль для развития современной еврейской прозы в США сыграл Хаим Поток (Chaim Potok, 1929-2002), который фактически впервые создал полноценные образы американских евреев-хасидов, а также поднял проблему взаимодействия ортодоксального иудаизма и американской действительности ${ }^{3}$.

Мы не можем однозначно причислить к американской еврейской литературе Нормана Мейлера. Несомненно, что он не только призна-

3 Эта проблема до сих пор является весьма актуальной, подтверждением чему может служить нашумевший мини-сериал «Неордотоксальная», выпущенный компанией Netflix в 2020 г. и вызвавший множество дискуссий не только в еврейской среде. 
вал свое происхождение, но оно нашло художественное воплощение в отдельных его произведениях. Мейлер также не раз высказывался о еврействе и собственной идентичности, и его имя включено в «Антологию американской еврейской литературы» издательства Norton (туда вошли его рецензии на двухтомник Мартина Бубера «Хасидские истории»). Однако этническая специфика не является значимой характеристикой его творчества в целом. Мы также не включаем в еврейскую литературу США таких писателей, как Джером Дэвид Сэлинджер и Пол Остер. Общеизвестно еврейское происхождение Сэлинджера и то, что семейство Глассов отражает семейную ситуацию автора: отец - еврей, мать - ирландка по происхождению, принявшая иудаизм, чтобы вступить в брак. Однако помимо этого факта, этническая специфика никак не проявляется в этих произведениях. Что касается Остера, то его интересуют вопросы еврейской идентичности, однако на сегодняшний день этническая специфика проявляется в его произведениях не настолько явно, чтобы причислить его к еврейской литературе, хотя, как утверждает Алики Варвогли в своей книге о нем, «...Остер не отделяет своего интереса к литературе от стремления обращаться к историческому прошлому, что ведет к исследованию и его собственного еврейского происхождения» [Varvogli 2001: 75].

Не становится предметом нашего исследования и творчество Э.Л. Доктороу, в произведениях которого присутствует еврейская тематика, однако она не является центральной.

Среди представителей молодого поколения мы выделяем уже признанных в США писателей: это Майкл Шейбон ${ }^{4}$ (Michael Chabon, p. 1963), Аллегра Гудман (Allegra Goodman, p. 1967), Джонатан Сафран Фоер (Jonathan Safran Foer, p. 1977), Николь Краусс (Nicole Krauss, p. 1974), Гари Штейнгарт (Gary Shteyngart, p. 1972)5. Сегодня

4 В большинстве русских изданий фамилия автора Чабон, однако мы, как и современная литературная критика, предпочитаем писать и произносить его фамилию в соответствии с англоязычным вариантом.

5 Творчество Штейнгарта стоит особняком в современной американской литературе. Уроженец Ленинграда Игорь Штейнгарт эмигрировал из СССР в детском возрасте в 1970-е вместе с родителями. Он является носителем сложного бордерного сознания, сформировавшегося на стыке советско-еврейского и американского менталитетов, что и отражается в его романах, ставших известными в США, причем не только в среде потомков или самих советских иммигрантов, но и у широкой публики. Как и у многих родившихся в СССР, самоидентификация Штейнгарта подразумевает больше этническую, культурную, а не религиозную составляющую: он считает себя евреем, но далек от иудаизма. Его творчество представляет новую тенденцию в развитии мультикультурной литературы США 
это наиболее заметные представители американской еврейской прозы, хотя в действительности писателей, которых можно причислить к этой категории, гораздо больше. В данной статье мы ориентируемся не только на известность авторов, но и на их доступность российскому читателю: произведения всех писателей, которых мы упоминаем, переведены на русский язык.

\section{Еврейский писатель как персонаж еврейской литературы}

Говоря об американской еврейской литературе второй половины XX - XXI в., можно обнаружить несколько наиболее характерных черт, определяющих ее самобытность. На первый план выходит проблема писательской и этнической идентичности. В попытках ответить на вопросы «Что такое еврейский писатель?» и «Что означает быть еврейским писателем в США?» авторы создают образы творческих личностей, которые часто являются автобиографическими. Так, сквозным персонажем в ряде романов Рота, созданных в 1970-2000-е гг., является alter ego автора Натан Цукерман, прошедший все стадии становления как писатель, успех и закат карьеры. Начиная с «Моей мужской правды» (My Life As a Man, 1974), где Цукерман - герой, созданный другим персонажем, и до романа «Призрак уходит» (Exit Ghost, 2007) читатель прослеживает эволюцию американского еврейского писателя.

Поиски идентичности оказываются центральной проблемой в романе Хеллера «Голд, или Не хуже золота» (Good As Gold, 1979), где завязкой сюжета является задание, которое протагонист получает от издателя: написать книгу об американских евреях.

Как я могу написать о жизни еврея, - спрашивал он себя в вагоне экспресса, возвращаясь в Нью-Йорк, - если я даже не знаю, что это такое? Я понятия не имею, о чем тут можно написать. Какая еще, к черту, жизнь еврея? По-моему, мне ни разу и не довелось встретить настоящего антисемита [Хеллер 1998: 5].

последних двух десятилетий и может быть поставлено в один ряд с творчеством таких писателей, как Халед Хоссейни и Джумпа Лахири. Все они, фактически, являются эмигрантами. Они приехали в США в детском возрасте с родителями, с уже отчасти сформированным менталитетом (Хоссейни - афганским, Лахири индийско-британским, Штейнгарт - советско-еврейским). Английский не является их родным языком, но свои произведения они создают именно на нем, и их романы успешны и признаны сегодня. 
Брюс Голд размышляет о себе и своем окружении, о том, что означает быть евреем в Америке и как создать реалистическую картину жизни евреев в США. Он мечтает занять пустующую на тот момент нишу в национальной литературе, став настоящим американским еврейским писателем. Хеллер показывает, что должен пережить писатель-еврей, чтобы создать по-настоящему еврейское произведение, но роман так и остается ненаписанным. Фактически персонаж Рота Цукерман делает то, что не удается персонажу Хеллера Голду, становится известным американским еврейским писателем и создает романы, которые находят отклик у всех американцев.

В проникнутом постмодернистской иронией романе «Видит Бог» (God Knows, 1984) Хеллер обращается к образу библейского царя Давида, которому иудейская традиция приписывает авторство знаменитых псалмов, считающихся первыми образцами авторской поэзии. Творчеству царя в романе уделяется немало внимания. Находясь на смертном одре, Давид вспоминает свою жизнь и свои произведения, одновременно анализируя их так, как будто живет на исходе XX столетия и знает классику мировой литературы. Свою элегию на смерть царя Саула и псалмы он называет гениальными. Он часто ссылается на других писателей, в основном новейшего времени, а также говорит о рецепции собственного творчества в последующие века: «Я написал серьезное поэтическое произведение, вовсе не намереваясь унижаться до скандальной публичной исповеди. Я - царь Давид, а не Оскар Уайльд...», - говорит он, объясняя слухи о его близких отношениях с сыном Саула Ионафаном, и смещая хронотоп, благодаря чему вписывает себя в историю мировой литературы [Хеллер 2002: 47].

Хеллеровский царь Давид также выступает как критик и литературовед. Так, он дает положительную оценку поэме Джона Мильтона «Самсон-борец» и ставит себя в один ряд с английским классиком:

Мы с ним поэты, а не историки и журналисты, и рассматривать его «Самсона-борца» следует в том же беспристрастном свете, что и мою знаменитую элегию на смерть Саула и Ионафана вместе с моими же псалмами, притчами и иными выдающимися произведениями. Цените их как поэмы. Ищите в наших творениях прежде всего красоту, а не точное изложение фактов [Хеллер 2002: 54].

Он рассуждает о поэтике, говорит о классификациях сюжетов в мировой литературе, предложенных различными исследователями 
в разные времена, и читатель забывает о том, что они были созданы намного позже, чем жил легендарный царь. Герой-повествователь не обходит своим вниманием «Песнь песней» - поэтический текст, авторство которого приписывается сыну Давида царю Соломону, воспевающему свою любовь к простой девушке Суламифи. Отрывки из этого текста «разбросаны» по всему роману, они появляются в речи Давида, когда он вспоминает первые годы жизни с любимой женой, однако они не оформлены как цитаты и представляют собой сложные аллюзии, распознать которые - задача читателя.

Одна из особенностей романа «Видит бог» состоит в том, что проблема идентичности, ни писательской, ни этнической, напрямую там не поднимается. То, что Давид не только царь Иудейский, но и еврейский поэт - факт, который воспринимается как должное. Однако у других авторов образ творческой личности обычно связан с вопросом идентичности. У представителей «молодого» поколения персонажи чаще всего проходят путь формирования и осознания себя еврейскими писателями через поиски корней и ощущение сопричастности истории. Это происходит с Лео Гурски - протагонистом романа Николь Краусс «История любви» (The History of Love, 2005), с автобиографическими героинями ее же романов «Большой дом» (Great House, 2010) и «В сумрачном лесу» (Forest Dark, 2017); с одним из двух главных героев романа Шейбона «Приключения Кавалера и Клея» (The Amazing Adventures of Kavalier \& Clay, 2000) Йозефом (Джо) Кавалером, бежавшим из оккупированной нацистами Праги в Америку и ставшим там создателем знаменитых комиксов; с протагонистом и повествователем романа Фоера «Полная иллюминация» (Everything is Illuminated, 2002), с одним из героев его же романа «Вот я» (Here I Am, 2016) - подростком, живущим в виртуальном мире, пишущим и создающим там «проекты» от имени аватара, своего вымышленного «я» и т. д.

Когда авторы сами создают образы американских еврейских писателей, возникает также проблема канона и потребность в эталоне. Персонажи-писатели во многих произведениях считают своими «учителями» классиков мировой литературы - Джойса, Чехова, Достоевского, Флобера и т. д. Но возникает проблема с эталоном именно еврейского писателя. Цукерман - персонаж, чье развитие и формирование как писательской личности мы наблюдаем на различных этапах жизни, в качестве образца истинно еврейского писателя видит Исаака Бабеля. Это и мнение самого Рота. Озик также считает Бабеля одним из наиболее значимых авторов XX столетия и часто обращается к нему 
в своих эссе, к которым можно отнести и ее блестящее предисловие к американскому изданию собрания сочинений Бабеля [Ozick 2002].

Для Рота и его героя Бабель - символ художественного совершенства, эталон стиля, и в то же время, пример того, чего может достичь еврейский писатель в условиях, которые вовсе не способствуют литературному успеху. Кроме того, это и пример личности, в которой соединилось несоединимое и разрушились стереотипы: интеллигентный еврей в очках, сражающийся в Красной армии и создающий тонкую и блестящую прозу с удивительным юмором. Именно это вызывает восхищение у героя романов Рота - молодого человека, родившегося в семье еврейских иммигрантов в штате Нью-Джерси:

Как радостно было найти свое имя среди списка годных к прохождению службы в школе военной полиции, штат Джорджия! Тут уж без обмана: сюда не зачислят кого ни попадя. Интеллектуал с пистолетом на боку, весь в хаки, о стрелку на брюках можно порезаться, преподаватель английского с полицейской дубинкой. Исаак Бабель не был тогда еще у нас издан, но через пять лет, прочтя его рассказы в мягкой обложке, я поразился нашему внутреннему сходству: Бабель, этот еврей-очкарик, ощущал свою причастность к толпе красных кавалеристов с такой же гордостью, как я, отправляясь на очередное дежурство, - общность со всем наличным составом военной полиции штата Джорджия [Рот 2002: 65].

Образцом литературного творчества и сложной бордерной идентичности становится для американских еврейских писателей и Франц Кафка. Не только Рот и Озик, размышлявшие над его творчеством, но и литературоведы давно сошлись во мнениях, что еврейство Кафки, хоть оно и не отражено в его произведениях напрямую, оказало решающее влияние на многое, что им написано. Кафка как личность и писатель играет важную роль в судьбе героя трех романов Рота писателя Дэвида Кепеша, который впервые осознает себя евреем, посетив могилу Кафки на Новом еврейском кладбище в Праге:

Подумать только! Каменное надгробие Кафки представляет собой прочный, вытянутый и суживающийся кверху фаллос из светлого камня. Вокруг не видно ничего подобного. Это первый сюрприз. Второй заключается в том, что сын, которого третировала семья, похоронен между матерью и отцом, который пережил его. Я беру камешек с посыпанной 
гравием дорожки и кладу его сверху каменной горки, насыпанной теми паломниками, которые побывали здесь раньше меня. Я никогда не делал ничего подобного для моих дедушки и бабушки, похороненных вместе с тысячами других людей на кладбище, протянувшемся вдоль скоростного шоссе в двадцати минутах езды от моей нью-йоркской квартиры; не навещал больше могилы моей матери на тенистом кладбище в Катскилле после того, как мы с отцом присутствовали при установке надгробья. На прямоугольных плитах, высящихся повсюду - знакомые еврейские фамилии. Я словно перелистываю свою записную книжку или смотрю через мамино плечо в список отдыхающих в «Королевском венгерском» (название отеля, который принадлежал родителям персонажа. O. $K$-A.): Левин, Гольдшмидт, Шнайдер, Хирш... Множество могил, но только за могилой Кафки, кажется, присматривают по-настоящему. < ..> Кажется, только один бездетный холостяк оставил после себя живущее потомство. Большей иронии, чем à la tomb de Franze Kafky, трудно себе представить. ...вдруг впервые замечаю таблички вдоль всей этой стены с именами евреев-пражан, истребленных в Терезине, Аусшвице, Белзене и Дахау. Я не смог бы найти такого количества камешков здесь вокруг [Рот 1994: 50].

Это кульминационная сцена романа «Профессор желания» (The Professor of Desire, 1977), к которой сходятся все нити повествования, и где Кепеш лицом к лицу сталкивается со всеми своими внутренними проблемами. Камни на еврейских могилах - символы его детских воспоминаний о родителях, отеле, которым они владели, о недавней смерти матери. Сама могила символизирует воображаемый мир, в который он погружается, а форма монумента становится фрейдистским символом его личных травм. Таблички с именами евреев, погибших в нацистских концлагерях, напоминают об истории, прошлом и о собственном еврействе, от которого он стремился отгородиться в попытках стать «настоящим американцем».

Вслед за Ротом к образу Кафки обращается Краусс, своеобразно продолжив тему его этнической идентичности и ее влияния на творчество в своем романе «В сумрачном лесу», одна из глав которого - альтернативная биография Кафки, где он предстает истинно еврейским писателем.

Таким образом, создавая персонажей-писателей и обращаясь к классикам мировой литературы, авторы отвечают для себя на вопрос о том, что означает быть еврейским писателем в США и как изобразить 
жизнь американских евреев «изнутри», но при этом выйти за рамки этнической замкнутости.

\section{Стереотипы. «Маленький человек» из гетто}

В своих произведениях американские еврейские писатели обращаются к отображению различных стереотипов (как тех, которые сложились о евреях, так и у евреев о самих себе), еврейскому юмору, теме Холокоста, проблемам религии, отношения к ней, степени религиозности и светскости. Как и в других этических литературах США (китайской, ирландской, мексиканской и т. д.) часто возникает конфликт поколений между родителями-иммигрантами и детьми, родившимися в США.

Еврейские стереотипы являются одним из главных объектов изображения для многих писателей. Как известно, «главное в стереотипном мышлении - стремление отделить себя и “своих" от “других”, свои национальные признаки от тех, которые якобы принадлежат “аутсайдеру”» [Филюшкина 2005: 142]. Такое стремление было особенно характерно для евреев как этнической и религиозной общности. Не имея своего государства на протяжении многих столетий, они держались обособленно в любой стране, где проживали, сохраняя закрытость своей общины, не одобряя межэтнические браки и т. д. Отчужденность также объяснялась вынужденной изоляцией и статусом преследуемого меньшинства. Такой образ жизни создал ментальность человека из гетто, где «гетто» могло быть как буквальным понятием, так и метафорическим. Все это способствовало формированию ряда стереотипов, связанных с религией, внешностью, образом жизни, на основе которых возникли хорошо известные из классической мировой литературы персонажи (Шейлок, Гобсек, Фейджин и т. д.). Уже в XX столетии появились и литературные стереотипы, созданные самими евреями. В первую очередь это образ местечкового еврея, возникший благодаря популярности произведений Шолом-Алейхема и их адаптациям, ставшим «хитами» кинематографа и мюзикла.

Еврейские писатели нередко иронизируют над типичными образами евреев, обыгрывая их. Юмор, ирония, сатира, сарказм стали инструментами, при помощи которых авторы играют со сложившимися стереотипами массового сознания. Автор книги «Современный еврейский литературный канон. Путешествие по языкам и странам» Р. Вайс пишет: «В 1894 году, когда Шолом-Алейхему было 35 лет, он создал персонажа по имени Тевье - деревенского еврея, обремененного не- 
замужними дочерьми, совсем как в идишской поговорке “Зибн техтер из ништ гелехтер” (“Семь дочек - тут уж не до смеха”). Поговорка смеется как раз над тем, что, по ее же утверждению, к смеху никакого отношения не имеет, и, исходя из этой парадоксальной логики, Тевье будет обращать в юмор все беды и огорчения своей жизни» [Вайс 2008: 64]. Именно «парадоксальная логика» является основой еврейского литературного юмора, который включает в себя все оттенки комического и трансформирует реальность - рутинную, страшную и даже трагическую - в нечто смешное и забавное.

Во второй половине XX в. местечковый еврей, подобный Тевье-молочнику, фактически преобразовался в специфический образ «маленького человека», типичный для творчества писателей США. Таковыми, например, являются образы, созданные Вуди Алленом в кино и литературе: «Аллен создал свою маску, воспринимая все на свете так, как может и даже должен все на свете воспринимать “маленький человек" с глубокими еврейскими корнями - ужасно недоверчивый, всюду ищущий подвоха, признающий только критерии практической жизни, то недалекий и обезоруживающе черствый, то необыкновенно сметливый и проницательный» [Зверев 2002].

«Маленькие люди», обычные, заурядные, те, кого принято называть everymen, становятся персонажами рассказов Озик и Пейли, которые следуют реалистической манере еврейской малой прозы, получившей развитие благодаря Маламуду. Обе писательницы обращаются к этнической тематике в рамках одного топоса — еврейских кварталов Нью-Йорка. Быт и жизнь их обитателей обусловлены иммигрантским менталитетом. В крупнейшем мегаполисе мира, где доступны все достижения современной цивилизации, они остаются в своей замкнутой среде и оказываются маргиналами. Их речь, поведение, быт кажутся смешными и нелепыми, они будто «выпали» из времени, оставшись в том прошлом, где евреев преследовал постоянный страх гонений. Обе писательницы подчеркивают это использованием идиша, языка, в современном мире доступного очень малому количеству людей и вызывающего ассоциации с чертой оседлости.

Жизнь «маленьких людей» в еврейских кварталах выглядит комично и зачастую напоминает анекдот:

Как-то после войны по узкой улочке Нижнего Ист-Сайда медленно двигался похоронный кортеж. Машины, выехав с парковки у храма в Бронксе, направились к кладбищу на Стейтен-Айленде. Их 
путь пролегал мимо редакции последней в городе ежедневной газеты на идише. В газете было два редактора, их обязанности распределялись так: один печатал экземпляры очередного номера, а второй смотрел в окно. И, увидев похоронную процессию, кричал напарнику: «Эй, Мотл, печатай на один экземпляр меньше!» [Озик 2010: 8-9].

В этом анекдоте, включенном в рассказ, Озик намеренно создает диссонанс между местом действия - Нью-Йорком, на что указывают топонимы, - и ситуацией, из которой ясно, что читатели газеты на идише - старики, живущие прошлым и не вписавшиеся в реалии современной Америки.

Сборник рассказов Пейли на русском языке озаглавлен так же, как один из рассказов, - «Мечты на мертвом языке» (Dreamer in a Dead Language). Название подчеркивает не только то, что идиш постепенно «умирает» по мере того, как уменьшается количество людей, считающих его родным и использующих его в повседневной жизни, но и то, что мечты его носителей несбыточны. Персонажи рассказов Пейли - заурядные обыватели, иммигранты, замкнутые в своем мирке. Их проблемы, мечты, стремления связаны исключительно с бытовыми вопросами. Они часто попадают в нелепые ситуации, так как не знают окружающего мира, который находится за пределами еврейских кварталов. Так, в рассказе «Конкурс» (The Contest) главный герой по имени Фредди, признанный в своем узком кругу интеллектуал, умный и тонкий человек, становится жертвой явного мошенничества со стороны возлюбленной. Он соглашается на участие в конкурсе, объявленном газетой на идише, оказавшись единственным, кто «купился» на рекламный ход. Выполнив все условия, он так и не получил награды, так как ее присвоила его возлюбленная. Примечательно, что Фредди отлично владеет идишем, а его возлюбленная, тоже еврейка, говорит только по-английски, она давно отошла от всего, что связывало ее с еврейством, стала «настоящей американкой».

В рассказе Пейли «Время, которое насмеялось над нами» (In Time Which Made a Monkey of Us All) все персонажи - обитатели одного дома - безнадежно отстали от времени и прогресса, они одиноки и нелепы. Описывая их, автор упоминает, что они живут на пособие, то есть, так и не смогли найти ни работы, ни своего места в жизни. Автор описывает их с добродушным юмором. Например, об Эдди Тейтельбауме, чудаке-мечтателе, изобретателе странных вещей, придумывающем нелепый «глушитель войны» говорится: 
Глушитель войны закачали под слабым давлением во флаконы. Его иногда называют «смесью Тейтельбаума», и его состав по-испански напечатан на этикетке. Это одно из самых сильных средств борьбы с насекомыми. К сожалению, его плохо переносят рододендроны и старые комнатные фикусы [Пейли 2012: 65].

Как и персонажи Маламуда, герои рассказов Озик и Пейли живут в замкнутом мире добровольного гетто. Фактически это тот же «маленький город маленьких людей», каким является вымышленный Шолом-Алейхемом городок Касриловка за чертой оседлости в Российской империи рубежа XIX-XX вв., хотя причина замкнутости заключается вовсе не в дискриминационной государственной политике, а в иммигрантском менталитете и невозможности преодолеть страх.

\section{Стереотипы. «Еврейская мама»}

Значительная часть стереотипов массового сознания связана с образом еврейской семьи, и в частности доминирующей роли матери в ней. Аидише мама (идишское выражение, давно вошедшее в обиход в разных языках) является главой семьи, она устанавливает правила и контролирует всех домочадцев. Это центральный образ многих анекдотов, как, например, «Чем отличается террорист от еврейской мамы? С террористом можно договориться». Наряду с диктаторскими качествами стереотипной чертой еврейской мамы является гипертрофированная забота о детях, даже когда они уже взрослые. Типичен анекдот: «Мама: “Изя, домой!” Изя: “Мама, я что, проголодался?” Мама: “Нет, ты замерз”». Подобные шутки характерны и для американской культуры.

Хрестоматийным примером аидише мамы в американской еврейской литературе стала героиня скандального романа Рота «Случай Портного» (Portnoy's Complaint, 1969) Софи, мать протагониста и повествователя Алекса Портного. В своем монологе в кабинете психоаналитика он постоянно обращается к образу матери. Для читателя ситуация выглядит анекдотично, герой же в свои 33 года страдает рядом неврозов и не может избавиться от навязчивого ощущения постоянного контроля. "The Most Unforgettable Character I've Met" так называется одна из глав романа, которая представляет собой игру слов: character может переводиться и как «персонаж», и как «человек с сильным характером». Роман, являющийся «исповедью» героя перед доктором, - это история его попыток оторваться от вездесущей мате- 
ринской заботы. Образ матери с детства преследует Алекса повсюду, вызывая одновременно страх и восхищение:

Это настолько владело моим сознанием, что весь первый класс в каждой учительнице мне мерещилась моя мать, только переодетая. После уроков я пулей летел домой, одержимый идеей поспеть туда раньше, чем она вернет себе прежний облик или, на худой конец, застукать ее за этим занятием. Однако ко времени моего прихода она уже наливала мне, стоя на кухне, стакан молока и выставляла домашнее печенье. Но мои иллюзии от этого не развеивались, я еще более поражался ее мастерству таинственных перемещений и мгновенных перевоплощений [Рот 2001: 6].

Такое отношение ведет к развитию эдипова комплекса, при котором восхищение матерью и осознание ее превосходства во всех сферах начинает вызывать подсознательные сексуальные желания, причем, если для Алекса это становится трагедией, то для читателя ситуация выглядит откровенно смешной.

В образе Софи Портной происходит слияние двух стереотипов: один уходит своими корнями в еврейский анекдот, другой - во фрейдизм. Очевидно, что под влиянием этого образа из романа Рота Вуди Аллен создал героиню - еврейскую маму в фильме «Нью-Йоркские истории» (New York Stories, 1989), в новелле Oedipus Wrecks' выступает в качестве актера, режиссера и сценариста. Аллен доводит ситуацию до абсурда: мать главного героя, физически исчезнув, в то же время становится вездесущей, появляясь в небе над Нью-Йорком и давая бесконечные советы сыну.

Американские писатели добавляют к анекдотическому образу аидише мамы такую специфическую черту иммигрантского менталитета, как стремление оградить своих чад от «пагубного» влияния американской цивилизации. Матери изобретают правила и запреты, которые в сознании героев прочно связываются с понятием еврейства, вызывая реакцию отторжения и, как следствие, неврозы. Герои часто пытаются начать «настоящую» американскую жизнь, в которой видят единственный путь освобождения от навязчивой материнской опеки.

6 Название новеллы является игрой слов, поэтому в русскоязычных версиях фильма можно встретить переводы «Эдипов комплекс», «Гибель Эдипа», «Новый Эдип», «Кошмарная мамочка». 
Этот мотив можно встретить во многих романах Рота, рассказах Вуди Аллена, Пейли и Озик, в романах Хеллера и т. д.

\section{Иудаизм}

Тема семьи занимает значительное место в произведениях еврейских писателей. Как мы уже отмечали, изображение конфликта поколений в семье - характерная черта расовых и этнических литератур США. Она непосредственно связана с формированием бордерного сознания. В еврейской литературе конфликт отцов и детей зачастую происходит из-за религии. Законы, регулирующие жизнь евреев, а также большинство запретов происходили из религиозных установок, зафиксированных в священных текстах. Те, кто иммигрировал в США из Европы, еще старались придерживаться строгих правил иудейского образа жизни, однако их дети и внуки зачастую отходили от них, все более становясь американцами, не зная идиша и не желая учить иврит - язык священных текстов. Осознание свободы выбора образования, карьеры, личной жизни заставляло их покидать еврейские кварталы с их добровольной замкнутостью, что и приводило к конфликтам между детьми и родителями. Самым известным произведением, раскрывающим этот конфликт и вышедшим на уровень национальной литературы, стал роман Хаима Потока «Избранник» (The Chosen, 1967). Он был экранизирован в 1980-е, а затем послужил основой для бродвейского мюзикла. Сегодня этот роман включают в категорию подростковой литературы как историю юношей, которые, взрослея, впервые в жизни принимают важные решения. Это позволяет поставить его в один ряд с такими историями формирования характеров, как «Приключения Гекльберри Финна» Марка Твена, рассказы о Нике Адамсе Хемингуэя и «Над пропастью во ржи» Сэлинджера. Особенность романа Потока состоит в том, что типичная для американской литературы тема раскрывается на этническом материале. Автор трансформирует собственный опыт как иммигранта, еврея, получившего религиозное образование, раввина и одновременно американского писателя.

В романе «Избранник» конфликт поколений в ультраортодоксальной еврейской семье показан глазами повествователя, подростка Рувима, который рассказывает историю своего друга Дэнни, родившегося в семье цадика (праведника), лидера закрытой общины, но решившего порвать с ней и со своим отцом ради мечты выучиться на психоаналитика. 
Фактически этот роман стал энциклопедией еврейской жизни для американского читателя благодаря интересному сюжету, реалистичности персонажей и ясности повествовательной манеры Потока, которому удается объяснить нюансы иудаизма в доступной форме. Он рассказывает о жизни в еврейских кварталах Нью-Йорка, делая акцент на бордерной идентичности детей, родившихся в США, тогда как их родители остаются носителями иммигрантского менталитета и сохраняют те страхи, которые веками формировались у евреев Европы.

Религиозному конфликту в «Избраннике» отводится та же роль, что расовому конфликту в «Приключениях Гекльберри Финна»: герой Марка Твена в своей эволюции проходит через преодоление расовых стереотипов, а герой Потока преодолевает стереотипы, продиктованные иудаизмом хасидского толка. К. Макклаймонд справедливо отмечает, что писатель «не противопоставляет иудаизм американскому культурному мейнстриму, а скорее показывает его как феномен, который должен интегрироваться в американскую жизнь. <..> В результате рядовые читатели, как евреи, так и неевреи, воспринимают роман "Избранник" как собственную американскую историю» [McClymond 2007].

Поток в своем романе показал, что религия имеет различные формы выражения, а в иудаизме может быть множество течений. Эту тему в 1990-е развивает Аллегра Гудман в сборнике рассказов «Семья Марковиц» (The Family Markowitz, 1996). Писательница выросла на Гавайях, в городе Гонолулу, в семье, принадлежащей к консервативному иудаизму ${ }^{7}$. Очевидно, что ее мировоззрение во многом сформировано экзотическим сочетанием места, где традиционно численность еврейского населения очень незначительна, и умеренно либеральным ответвлением иудаизма. «Семья Марковиц» - цикл реалистических рассказов, где каждый самостоятелен по сюжету и структуре и представляет собой эпизод из жизни одного из членов семьи, при этом в сборнике складывается целостная картина жизни типичной американской еврейской семьи конца XX в. ${ }^{8}$

7 Вопреки названию «консервативный» это современное течение в иудаизме, которое характеризуется более гибким по сравнению с ортодоксальным отношением к догмам и ритуалам. Его можно рассматривать как промежуточный вариант между ортодоксальным, где требуется неукоснительное соблюдение всех норм, закрепленных в древности, и прогрессивным (реформистским) иудаизмом. Фактически это попытка достичь компромисса между древним вероучением и требованиями современности.

8 Реалистичная манера повествования и изображение разнообразных конфликтов в рамках типичной американской семьи, принадлежащей к среднему 
Как и в романе Потока, в рассказах Гудман одним из центральных становится конфликт поколений на религиозной почве, однако уже в современном варианте, когда поколения фактически меняются местами: родители оказываются менее религиозными, чем дети. Если для старшего поколения свобода выбора означала отход от религиозных традиций, то для младшего эта же свобода выражается в решении следовать иудейским законам, что является формой самоидентификации и самовыражения. Один из героев цикла Эд Марковиц - типичный образ современного еврея-интеллектуала. Профессор, специалист по современному Ближнему Востоку, он часто ездит на конференции, выступает на радио и телевидении. Как и его пожилые родители, он осознает себя евреем, но это не занимает его мыслей всерьез, оставаясь само собой разумеющимся фактором жизни. Семья привычно посещает синагогу несколько раз в год на праздники и устраивает застолья на Песах, не следуя строгим правилам, как это и делает множество еврейских семей в США. Конфликт возникает, когда дочь Эда Мириам, студентка медицинского факультета Гарварда, обращается к ортодоксальном иудаизму и начинает соблюдать все заповеди, что прежде всего отражается в быту. Например, она категорически отказывается есть из обычной посуды в доме родителей, считая ее некошерной, настаивает на жестком разделении мясного и молочного и т. п. По-американски прагматичный Эд, во всем предпочитающий разумный подход, не может понять, как современная девушка, выбравшая медицину в качестве профессии, может быть так привержена запретам и правилам, возникшим тысячелетия назад и давно утратившим всякий смысл:

Они воспитывали детей так, чтобы те выросли либеральными, рациональными, жизнелюбивыми, чтобы еврейские традиции были им в радость, и почему вдруг Мириам выбрала путь самоограничения и непостижимой обрядности, Эд понять не может. Ей всего двадцать три, пусть она и выходит замуж. Как может совсем молоденькая девушка так держаться буквы закона? Его это гнетет [Гудман 2013].

Гудман, писательница современная, занимает более жесткую позицию относительно религии, чем Поток в конце 1960-х. Если Поток во многом сочувствует иммигранту-хасиду, объясняя его неприятие

классу, позволяет нам сравнить этот сборник с циклом «Рассказы о Маплах» Дж. Апдайка. 
современной жизни теми преследованиями, которые ему пришлось пережить до переезда в США, то Гудман явно осуждает соблюдение неразумных правил и одобряет умеренность в религии, которая позволяет евреям сохранять себя как этнос и одновременно быть полноценной частью американского общества, стремясь к воплощению «американской мечты». Компромиссным решением для нее является консервативный иудаизм, который признан только в США.

К теме религии обращается в своих рассказах Вуди Аллен, однако, в отличие от Потока и Гудман, он не изображает острых конфликтов, а создает комическую картину жизни американских хасидов в Бруклине, показывая их как неотъемлемую часть современного Нью-Йорка и в то же время экзотическую закрытую общину, вызывающую любопытство. Примером этому являются пародийные «Хасидские притчи с руководством по их толкованию, составленным выдающимся талмудистом» (Hassidic Tales, With a Guide to their Interpretation by the Noted Scholar, 1970) - короткие сатирические рассказы, близкие по жанру к анекдотам. Аллен пародирует истории о мудрецах и цадиках, сопровождаемые, согласно традиции, комментариями и интерпретациями, в которых и должна заключаться основная мудрость. Он сохраняет форму притчи, наполняя ее абсурдным и нелепым содержанием, создавая тем самым комический эффект. В каждой «притче» главным героем является мудрец-раввин, которому автор дает имя, напоминающее настоящие хасидские имена на идише, зачастую с упоминанием места: рабби Радиц из Польши, краковский рабби Шиммель, рабби Бомель из Витебска и т. д. Эти «мудрецы» предстают как комические фигуры как внешне, так и по характеру: «рабби Радиц из Польши был длиннобородым раввином очень маленького роста, о нем говорили, что присущее ему чувство юмора вдохновило немало еврейских погромов» [Аллен 2002: 58]; «рабби Цви Хайм Изроэль, правоверный толкователь Торы, человек, поднявший искусство жалобного нытья до высот, неслыханных на Западе...» [Аллен 2002: 61].

Следуя своей сатирической манере, Аллен пародирует не только форму хасидских притч, но и назидательный стиль комментариев к ним, снижая пафос мудрых высказываний до быта, а зачастую и физиологии. «Хасидские притчи» Аллена нельзя назвать примером тонкого юмора, а его приемы не требуют от читателя размышления и разгадывания. Автор следует традициям американского «дикого юмора» фронтира, превращенного Марком Твеном в национальный феномен. Все его характерные элементы — гротескные образы, байки, 
анекдоты и т. д. - Аллен использует на еврейском материале, высмеивая этнические стереотипы, связанные с религией.

В традициях «дикого юмора» высмеивают иудейские ритуалы и писатели «младшего» поколения Гари Штейнгарт и Майкл Шейбон. В своем сатирическом романе «Абсурдистан» (Absurdistan, 2006) Штейнгарт выражает абсолютное неприятие ритуальной стороны иудаизма. Главный герой Миша Вайнберг, родившийся в Ленинграде и переехавший в США, где стал специалистом по мультикультурализму, вспоминает о самом травматичном (в прямом и переносном смысле) эпизоде своей жизни. Когда он переехал в Нью-Йорк, ему по настоянию отца сделали обрезание, за которым последовали осложнения, породившие у Миши комплекс неполноценности. Бруклинских хасидов повествователь описывает как неопрятных алкоголиков, а саму церемонию как варварский ритуал:

Когда я проснулся, надо мной молились мужчины в черных шляпах, и я ничего не чувствовал там, ниже пояса, под аккуратно подоткнутыми складками плоти. Я поднял голову. На мне была зеленая больничная одежда, внизу прорезана круглая дырка, и там, между мягкими подушками моих бедер, неподвижно лежал он, багровый и раздавленный, и из его оболочки сочилась жидкость; анестезия притупляла боль.

По какой-то причине мои единоверцы решили, будто моя рвота - признак того, что я очнулся. Они вытерли мне подбородок, рассмеялись и сказали:

— Mazel tov! Tsimmus tov! Heg, bey, Yisroel!

Той ночью у меня началось заражение [Штейнгарт 2007: 15].

Если у Штейнгарта хасиды - это просто неприятные, неопрятные, необразованные и одержимые исполнением обрядов люди, то в романе Шейбона «Союз еврейских полисменов» (The Yiddish Policemen's Union, 2007) они предстают как крайне агрессивная преступная группировка. Создавая образ вымышленной еврейской колонии на Аляске в романе, представляющем собой альтернативную историю, Шейбон не мог обойти вниманием ультраортодоксальных иудеев. Он сделал их преступниками, с которыми борются еврейские же полицейские, обеспечивающие порядок в колонии. По мере развития сюжета в стиле «крутого детектива» выясняется, что «Черные шляпы» - это не просто религиозная секта и преступная группировка, а настоящая 
террористическая организация. Сатира Шейбона выглядит непримиримой и жесткой.

Таким образом, в современной американской еврейской литературе мы видим различное отношение авторов к иудаизму и как к вере, и как к набору религиозных практик - от попыток понять даже самые радикальные ультраортодоксальные его течения, до иронии, сатиры и полного неприятия, открытого, а иногда и весьма агрессивного осуждения ритуалов и образа жизни.

\section{Холокост как феномен коллективной памяти}

Несмотря на дискуссии вокруг иудаизма и его различных течений, сегодня религия далеко не всегда является основой еврейского самосознания, еврейского опыта, о котором говорил Маламуд, и не все авторы поднимают вопросы религии в своих произведениях. Как мы уже отмечали выше, фактически единственная тема, которая становится общей для всех представителей современной еврейской литературы, независимо от национальной принадлежности автора, страны проживания и языка, - Холокост, который стал феноменом коллективной памяти. Хотя американские евреи оказались в лучшем положении, чем европейские, и не подвергались планомерному уничтожению, ужас, вызванный катастрофой, не мог не сказаться на их мироощущении. Осознание причастности к трагедии - характерная черта американской еврейской литературы, как и любой другой еврейской литературы сегодня. Тему Холокоста не обходит ни один из писателей‥

9 В данной статье мы намеренно не касаемся современной массовой литературы, в которой тема Холокоста является одной из главных. Каждый год появляются все новые и новые произведения, каждое из которых основано на семейной истории, воспоминаниях и других документах. Они зачастую становятся национальным бестселлерами, хотя далеко не всегда представляют собой эстетическую ценность. Примером таковых можно назвать одни из самых популярных в последние годы романов «Жена смотрителя зоопарка» Д. Акерман (The Zookeeper's Wife. A War Story, 2007, экранизирован в 2017 г.) и «День, когда мы были счастливы» Д. Хантер (We Were the Lucky Ones, 2017). Заметим, что оба бестселлера не обладают явными художественными достоинствами и представляют собой довольно сухое изложение реальных событий. В первом случае оно основано на мемуарах Антонины Жабинской, жены директора Варшавского зоопарка, во втором - на истории предков самой Хантер. Услышав ее в подростковом возрасте, она была настолько потрясена, что, став взрослой, решила «взяться за перо». В обоих случаях рассказываются истории выживших со счастливым финалом. Сцены расправ над евреями смягчены и носят эпизодический характер. Таким образом, сегодня можно говорить о конъюнктурности темы Холокоста в западной литературе, а также в кинематографе. 
Мы можем говорить о двух тенденциях в художественном отображении Холокоста американскими еврейскими писателями, в зависимости от того, к какому поколению они принадлежат. Так, авторы, ставшие, пусть и в детском возрасте, современниками событий, воспринимают трагедию не как историческое прошлое, а как часть собственной жизни. Они слушали рассказы своих родителей и близких родственников, часто в их семьях были погибшие или выжившие в нацистских лагерях и гетто. Их творчество характеризует документализм, что в целом типично для произведений о войне, нацизме и Холокосте, так как психологическое потрясение от произошедшего превзошло человеческое воображение. Вторая тенденция - это уже не осмысление, а переосмысление трагедии, чаще всего с позиций постмодернизма. Она характерна для писателей, которые принадлежат к поколению внуков и правнуков современников и жертв Холокоста. Для них произошедшее - неотъемлемая часть исторической памяти, а также связующее звено между ними и предыдущими поколениями. Для этих писателей характерен синтез жанров и соединение трагического и комического. Одним из наиболее ярких примеров произведений о Холокосте синтетического жанра стал графический роман Арта Шпигельмана (Art Spiegelman, p. 1948) «Mayc» (Maus, 1980), соединивший в себе документализм и необычную форму преподнесения фактов.

Представитель «старшего» поколения X. Поток в романе «Избранник», где действие происходит в конце 1940-х, описывает восприятие событий их современниками, американскими подростками, показывая непосредственную реакцию на приходящие из Европы новости:

Я не в силах был этого осознать. Количество уничтоженных евреев колебалось от одного до трех-четырех миллионов, и почти в каждой газетной статье делалась оговорка, что счет еще неполон, что общее количество может достигнуть шести миллионов. Я даже представить себе не мог шесть миллионов моих соплеменников уничтоженными. Я лежал и пытался понять, какой в этом смысл. Но смысла никак не находилось. Мой разум отказывался это принять смерть шести миллионов человек [Поток 2013: 211-212].

Герои ощущают собственную причастность к трагедии, у них возникает «комплекс вины выжившего». Трагедия оказывает решающее влияние на формирование их американо-еврейской идентичности. 
Оба подростка, главные герои романа, осознают себя американскими евреями, и будучи глубоко религиозными, видят свое предназначение в том, чтобы не допустить повторения трагедии.

В отличие от Потока С. Озик обращается не к восприятию трагедии, а к ее непосредственному описанию. Рассказ «Шаль» (The $S h a w l)$ - одно из сильнейших реалистических произведений о Холокосте в литературе США, написанное в жанре «концлагерного романа». Его действие происходит в Европе, а герои не наблюдатели, а жертвы трагедии: еврейская женщина Роза пытается спасти немецкую девочку Магду и оказывается вместе с ней и своей дочерью Стеллой в концлагере. Шаль в рассказе является вещественным образом-символом: маленькая Магда ищет в ней убежища и сосет ее уголок, в то время как Стелла, девочка-подросток, с завистью наблюдает за Магдой, мучаясь от голода. Читателю очевидно, что шаль - лишь иллюзия надежды на спасение, и все три героини обречены. Озик использует короткие, лаконичные предложения, вызывая сильную эмоциональную реакцию читателя:

Роза понимала: Магда скоро умрет, она бы уже давно умерла, но схоронилась в волшебной шали <..> Никто эту шаль у Розы не забрал. Магда онемела. Она никогда не плакала. В бараке Роза прятала ее под шалью, но понимала, что кто-нибудь рано или поздно донесет, или кто-нибудь, даже не Стелла, украдет Магду, чтобы ее съесть [Озик 2012: 4].

Рассказ шокирует читателя натуралистичным описанием концлагерной жизни, и автор усугубляет ощущение ужаса финальной сценой - расстрелом Магды, только что сделавшей свои первые шаги и случайно вышедшей из барака. При этом нацисты не подозревают о том, что убивают своего, арийского ребенка. Озик не дает читателю ни малейшего ощущения надежды на спасение, она лишь подчеркивает обреченность героев: если бы Магда не была расстреляна, она бы все равно погибла от голода или в газовой камере вместе с Розой и ее дочерью.

Произведения Потока и Озик являются прямой реакцией на трагические события и показывают их с точки зрения современников, пусть и находящихся на большом расстоянии от места трагедии. Рот, а также авторы «молодого» поколения — Фоер, Краусс, Шейбон, - переосмысливают события с точки зрения постмодернистской 
эстетики. Так, одним из способов художественного отражения трагедии становится альтернативная история. В романе Рота «Призрак писателя» (The Ghost Writer, 1979) Натан Цукерман, начинающий писатель, делает допущение, что девушка, с которой он познакомился в доме своего наставника, - выжившая Анна Франк. Писательское воображение рисует ему весьма правдоподобную картину того, что могло бы произойти: в феврале 1945 г. в лагере Берген-Бельзен Анну перепутали с умершей сестрой Марго; через месяц узники лагеря были освобождены, и девочку-подростка вывезли в США, где она выросла под именем Эми. Когда в середине 1950-х был опубликован на английском языке дневник Анны Франк «Убежище», Эми решила не раскрывать правды. Хотя первым ее порывом было выйти на связь с отцом - единственным выжившим из всех обитателей «убежища», она приняла решение не разрушать красивый и трагический миф о девочке-подростке, жертве нацизма, которая оставила дневник, ставший не только одним из главных документальных свидетельств Холокоста, но и известнейшим произведением литературы. Такой сюжетный ход нужен Роту для того, чтобы показать один из этапов формирования идентичности американского еврейского писателя - протагониста Натана Цукермана. А Анна-Эми в его воображении - пример жертвенности ради литературы.

С той же проблемой идентичности еврейского писателя связывает альтернативную историю и Краусс в своем романе «В сумрачном лесу», где, как мы упоминали выше, основой одной из сюжетных линий становятся события Холокоста и биография Кафки и членов его семьи: три сестры писателя погибли в нацистских лагерях смерти, что, скорее всего, ждало бы и его самого, если бы не ранняя смерть в 1924 г. Героиня романа американская писательница Николь, приехав в Израиль, знакомится с человеком, который рассказывает ей «правду» о Кафке: он не умер в санатории в Австрии, а тайно переехал в Палестину, где прожил до 1956 г.

Из прежней жизни он взял только свое еврейское имя, Аншель. <..> Туберкулез, который убил бы его в Праге, в Палестине начал постепенно отступать. $<\ldots>$ Вновь построенный район Рехавия (в Тель-Авиве. - O. K.-A.), сказал он мне, вскоре заполнился интеллектуалами из Берлина и Вены. <...> Кафка переехал туда в 1925 году, и в том же году Брод опубликовал в Европе «Процесс». Уже тогда был риск, что в Рехавии писатель встретит кого-то, кто знал его по 
старой жизни, но в следующем году, когда в Европе вышел «Замок», ситуация стала совсем безвыходной. По его собственной просьбе Кафку перевезли в кибуц на севере, рядом с Галилейским морем. < ..> В 1953 году садовник Аншель Пелег в последний раз переехал. <..> После пятнадцати лет в кибуце и вечных переездов в Тель-Авиве вещей у него было мало [Краусс 2019: 203-225].

Этот сюжет составляет целую главу романа под названием «Гилгуль» (в переводе с иврита — «Превращение»), это же название в ивритском издании носит и самая знаменитая новелла Кафки.

Рот и Краусс обращаются к образам реальных творческих личностей, чьи судьбы прямо и косвенно связаны с Холокостом, что становится одним из вариантов постмодернистского переосмысления трагедии.

Одна из самых ярких альтернативных историй последних десятилетий - роман Рота «Заговор против Америки» (The Plot Against America, 2004), ставший особенно популярным в последнее время: в 2020 г. компания $H B O$ выпустила одноименный телесериал. Тема Холокоста присутствует в романе имплицитно, но он является одним из наиболее значимых произведений о фашизме, написанных в XXI в., хотя идея о том, что США могут стать фашистской державой, уже высказывалась задолго до его публикации: в 1935 г. вышел роман Синклера Льюиса «У нас это невозможно» (It Can't Happen Here) антиутопия, в которой рассказывается, как в 1937 г. на пост президента США избирается человек фашистских взглядов. Тогда, спустя всего год после прихода к власти Гитлера в Германии, подобное произведение в Америке воспринималось как предупреждение. Спустя почти 70 лет Рот создает так называемую what-if-story, делая гипотетическое предположение, что президентские выборы в 1940 г. выигрывает знаменитый летчик, национальный герой Чарльз Линдберг, чьи политические взгляды близки к нацистским. На примере семьи главного героя, маленького мальчика по имени Филип, автор показывает, как меняется жизнь американцев, и в первую очередь американских евреев. Трагедия европейского еврейства в романе не упоминается, однако читатель воспринимает сюжетные перипетии с точки зрения современности, со знанием о ней и ее последствиях. Поэтому некоторые сцены романа приобретают трагически-ироничное звучание. Таковым является эпизод приезда Гитлера и Евы Браун в Вашингтон с официальным государственным визитом. Их встречают президент и первая леди, в их 
честь дается бал, на котором в числе приглашенных присутствует поддерживающий Линдберга раввин и его невеста - тетя главного героя. Почетным гостям для ночевки в Белом доме выделена спальня, некогда принадлежавшая Аврааму Линкольну ${ }^{10}$. Гитлер, спящий в постели президента, отменившего рабство, — такой абсурдный образ создает автор в воображении читателя.

Фактически Рот переосмысливает причины и следствия нацизма с точки зрения XXI в., когда уже почти не осталось живых свидетелей трагедии, и она сама превращается в миф и многократно тиражируется в массовой культуре. Его произведение - роман-предупреждение, и сериал, снятый по его мотивам, подтверждает его актуальность.

С помощью методов постмодернизма переосмысливают трагедию писатели «молодого» поколения. Фактически ряд произведений о Холокосте в американской литературе нового тысячелетия открыл роман Шейбона «Приключения Кавалера и Клея», написанный в трагикомическом ключе. В нем рассказывается история двоюродных братьев-евреев, один из которых, Сэм, родился и вырос в Нью-Йорке, другой, Йозеф - в Праге. Йозефу удалось бежать из оккупированного нацистами города при невероятных обстоятельствах - в гробу со «спящим» Големом, которого, согласно фантазии автора, пражские евреи решили тайно вывезти. Невероятные приключения в романе переплетаются со страшными сценами входа нацистов в Прагу, жизни евреев в гетто, гибелью родителей Йозефа и его младшего брата. Избежав трагедии, сменив имя и став вместе с двоюродным братом автором популярнейших в Америке комиксов, Джо (Йозеф) Кавалер всю жизнь несет в себе «комплекс вины выжившего». До нацистской оккупации он не задумывался над своим происхождением, но, наблюдая за происходящим и постепенно узнавая о судьбах близких, он начинает ощущать себя евреем, и причастность к трагедии становится частью его мировоззрения. Спустя многие годы он создает свой лучший комикс, в котором подсознательно воспроизводит атмосферу знаменитых еврейских кварталов Праги:

«...изящные остроконечные башни и осыпающиеся арочные проходы города, <..> ряды причудливых домов, сгрудившихся

10 Следует отметить, что этот эпизод в телесериале был значительно смягчен: с официальном визитом в Белый дом прибыл не сам фюрер, а министр иностранных дел фон Риббентроп. 
в снегу, мост со статуями, что отбрасывал изломанную лунную тень на черную реку, извилистые проулки. Персонажи по большей части казались евреями - старомодными, в черных одеждах, - выписанными со свойственной Джо детальностью и плавностью линий. < ..> здесь были настоящие человеческие лица, худые, голодные, чьи глаза словно бы предчувствовали ужас, но в то же время по-прежнему на что-то надеялись» [Чабон 2006: 637].

Тема Холокоста, напрямую связанная с темой поиска и осознания корней, стала основной и в дебютном романе Фоера «Полная иллюминация», который, так же, как и «Приключения Кавалера и Клея» Шейбона, можно назвать трагикомическим. Сюжет романа фрагментарен, он распадается на несколько историй, повествование ведется от лица разных персонажей, но точкой соприкосновения сюжетных пластов становится Холокост. Без привязки к конкретным событиям и документам автор рассказывает о судьбе обитателей вымышленного украинского местечка Трахимброд/Софьевка и их уничтожении нацистами. Сцена уничтожения в романе также вымышленная, но она поражает своей натуралистичностью. О произошедшем рассказывает главным героям пожилая женщина - единственная обитательница местечка, кому случайно удалось выжить:

Они сорвали платье с моей старшей сестры. Она была беременна и с большим животом. < ..> Помню, ее трясло от холода, хотя было лето. Они стащили с нее трусы, и один из мужчин вложил пистолет в ее место, а другие до того смеялись, я всегда этот смех помню... [Фoep 2010: 240].

Точную характеристику роману дала Т.Н. Денисова: «Фактическим смыслом романных перипетий и становится поиск (квест) двумя столь разными действующими персонажами своей идентичности, ощутить которую невозможно, не почувствовав собственных истоков и корней, что оказываются, как узлом, связанными трагедией Холокоста» [Денисова 2009: 32]. Эти же слова можно отнести и к романам Краусс «Хроники любви» и «Большой дом». Их фрагментарные сюжеты напоминают пазлы, которые складываются в финале в единую картину. Герой «Хроник любви», американский еврей, переживший Холокост, наконец осознает свое прошлое и возвращается в своих воспоминаниях к первой любви, которая была еще до того, как нацисты 
оккупировали его родной город. Персонажи «Большого дома», люди разных поколений, живущие в разных странах, оказываются носителями одной психологической травмы и коллективной памяти, которая переходит в своеобразную одержимость трагедией, когда человек воспринимает весь мир только сквозь ее призму. Один из персонажей с крайним возмущением реагирует на то, что его сын приехал на автомобиле немецкой марки:

Машину эту ты, как приехал, взял напрокат. Внутри - все черное, кожаное. Что за машина? - спросил я. БМВ. Немецкая? Ты везешь меня домой на нацистской машине? Ты такая великая шишка, что не можешь, как все люди, ездить на «хюндае»? Корейцы для тебя недостаточно хороши? Специально переплачиваешь, лишь бы показаться на нацистской машине? Ее же собирали дети тех, кто гнал нас в газовые камеры! [Краусс 2013: 99].

Писательница показывает, что травматический опыт здесь трансформировался в коллективную память и породил у многих евреев неприязнь ко всему немецкому — от языка до автомобилей, сохраняющуюся на многие десятилетия.

В романе «В сумрачном лесу», где действие происходит в современном Израиле, героиня-писательница лицом к лицу сталкивается с ужасом Холокоста в обычном супермаркете:

В последнюю мою поездку старуха в летней шляпе с завязками под пухлым подбородком загнала меня в угол в супермаркете. Сжав мое запястье мясистыми пальцами, она заставила меня пятиться в молочный отдел, чтобы сказать, что для нее читать мои книги было не меньшей радостью, чем плевать на могилу Гитлера (хотя у него ее и не было), и что она будет читать все, что я напишу, пока сама не окажется в могиле [Краусс 2019: 91].

Сцена выглядит комично, читателю кажется, что упоминание Гитлера и его смерти — эмоционально окрашенная фигура речи, вызывающая неприязнь к чрезмерно экзальтированной женщине. Однако сцена имеет продолжение:

Я стояла, притиснутая к витрине с кошерным йогуртом, вежливо улыбалась и благодарила ее, и наконец, вскинув мою руку, словно я победитель в тяжелом весе, и крикнув мое имя равнодушной 
кассирше, она ушла, но на прощанье продемонстрировала потускневший зеленый номер, вытатуированный на внутренней стороне руки... [Kpaycc 2019: 91].

Эта татуировка, демонстрирующая, что женщина была когда-то узницей концлагеря, кардинально меняет отношение к ней читателей, создавая трагический диссонанс с окружением — картиной изобилия современного супермаркета.

Таким образом, Холокост становится не только фактором формирования современной еврейской идентичности, во многом заменяя религию, он также является связующим звеном между поколениями, и тема поиска корней через коллективную память выходит на первый план в произведениях писателей последних двух десятилетий.

В начале третьей декады XXI столетия американская еврейская литература, как мы видим, представляет собой не просто группу писателей, о которой говорил Маламуд в начале 70-х гг., и даже не «школу», в существовании которой он сомневался. Это уникальный феномен, который, с одной стороны, вписывается в самое общее понимание еврейской литературы со всем ее сегодняшним многообразием, с другой, является одной из важнейших составляющих мультикультурной литературы США. Мы можем наблюдать эволюцию творчества американских еврейских писателей со всем разнообразием жанров, стилей и методов, существующих в мировой словесности.

\section{ЛИТЕРАТУРА}

Аллен 2002 - Аллен В. Записки городского невротика, маленького очкастого еврея, вовремя бросившего писать. СПб.: Symposium, 2002. 338 с.

Вайс 2008 - Вайс Р. Современный еврейский литературный канон. Путешествие по языкам и странам. М.: Мосты культуры, 2008. 510 с.

Вольтская 2012 - Вольтская T. Книга «Бумажные мосты» // Радио Свобода: [сайт]. 21 июня 2012 г. URL: https://www.svoboda.org/a/24622403.html.

Гудман 2013 - Гудман А. Семья Марковиц. ЛитМир: электронная библиотека: [сайт]. URL: https://www.litmir.me/bd/?b=177699\&p=1 (дата публикации 16.10.2013).

Денисова 2009 - Денисова Т.Н. Всесвітні трагедії від Джонатана Сафрана Фоера // Слово і час. 2009. № 1. С. 28-38. 
Зверев 2002 - Зверев А.M. Триумф очкарика // Лехаим. 2002. № 7 (123). URL: https://lechaim.ru/ARHIV/123/n2.htm

Краусс 2013 - Краусс Н. Большой дом М.: Corpus, 2013. 448 с.

Краусс 2019 - Краусс Н. В сумрачном лесу. М.: Книжники, 2019. 320 с.

Озик 2010 - Озик $C$. Путермессер и московская родственница. М.: Текст; Книжники, 2010. 316 с.

Озик 2012 - Озик С. Шаль. М.: Текст; Книжники, 2012. 120 с.

Пейли 2012 - Пейли Г. Мечты на мертвом языке. М.: Текст; Книжники, 2012. 248 c.

Поток 2013 - Поток X. Избранник. М.: Текст; Книжники, 2013. 316 с.

Рот 1994 - Рот Ф. Болезнь Портного. Профессор желания. Прощай, Коламбус. Вильнюс: Полина, 1994. 508 с.

Рот 2002 - Рот Ф. Моя мужская правда. СПб.: Лимбус Пресс, 2002. 376 с.

Рот 2001 - Рот Ф. Случай Портного. СПб.: Лимбус Пресс, 2001. 286 с.

Филюшкина 2005 - Филюшкина С.Н. Национальный стереотип в массовом сознании и литературе (опыт исследовательского подхода) // Логос. 2005. № 4 (49). С. 141-155.

Фоер 2010 - Фоер Дж.С. Полная иллюминация. М.: Эксмо, 2010. 352 с.

Хеллер 2002 - Хеллер Дж. Видит Бог. М.: Иностранка; Б.С.Г.-Пресс, 2002. 574 c.

Хеллер 1998 - Хеллер Дж. Голд, или Не хуже золота. М.: АСТ; Харьков: Фолио, 1998. 445 с.

Чабон 2006 - Чабон М. Приключения Кавалера и Клея. СПб.: Амфора, 2006. 750 c.

Штейнгарт 2007 - Штейнгарт Г. Абсурдистан. М.: Амфора, 2007. 477 с.

\section{REFERENCES}

Allen 2002 - Allen, Woody. Zapiski gorodskogo nevrotika, malen'kogo ochkastogo evreia, vovremia brosivshego pisat' [Notes of the Urban Neurotic, Small Bespectacled Jew, Who Gave up Writing Before It Was Too Late]. St. Petersburg: Symposium Publ., 2002. (In Russ.)

Budick 2001 — Budick, Emily M., ed. Ideology and Jewish Identity in Israeli and American Literature. Albany: State University of New York Press, 2001.

Chabon 2006 - Chabon, Michael. Prikliucheniia Kavalera i Kleia [The Amazing Adventures of Kavalier and Clay]. St. Petersburg: Amphora Publ., 2006. (In Russ.)

Chametzky et al. 2000 - Chametzky, Jules, John Felstiner, Hilene Flanzbaum, and Kathryn Hellerstein, eds. Jewish American Literature: A Norton Anthology. New York: W.W. Norton, 2000. 
Denisova 2009 - Denisova, Tamara N. "Vsesvitni tragediï vid Dzhonatana Safrana Foera." ["The Universal Tragedies by Jonathan Safran Foer."] Slovo i chas, no. 1 (2009): 28-38. (In Ukrainian)

Filiushkina 2005 - Filiushkina, Svetlana N. "Natsional'nyi stereotip v massovom soznanii i literature" ["National stereotype in mass consciousness and literature (experience of the research approach)"']. Logos 49, no. 4 (2005): 141-155. (In Russ.)

Foer 2010 - Foer, Jonathan S. Polnaia illiuminatsiia [Everything is Illuminated]. Moscow: Eksmo Publ., 2010. (In Russ.)

Gudman 2013 - Gudman, Allegra. Sem'ia Markovits [The Family Markowitz]. LitMir: electronic library: [website]. Updated October 16, 2013. https://www. litmir.me/br/?b=177699\&p=1. (In Russ.)

Heller 1998 - Heller, Joseph. Gold, ili Ne khuzhe zolota [Good As Gold]. Moscow: AST Publ.; Khar'kov: Folio Publ., 1998. (In Russ.)

Heller 2002 - Heller, Joseph. Vidit bog [God Knows]. Moscow: Inostranka Publ.; B.S.G.-Press Publ., 2002. (In Russ.)

Krauss 2013 - Krauss, Nicole. Bol'shoi dom [Great House]. Moscow: Corpus Publ., 2013. (In Russ.)

Krauss 2019 - Krauss, Nicole. V sumrachnom lesu [Forest Dark]. Moscow: Tekst Publ.; Knizhniki Publ., 2019. (In Russ.)

Malamud 1996 - Malamud, Bernard. Talking Horse. Bernard Malamud on Life and Work. Edited by Alan Cheuse, Nicholas Delbanco. New York: Columbia University Press, 1996.

McClymond 2007 - McClymond, Kathryn. "The Chosen: Defining American Judaism." Shofar: An Interdisciplinary Journal of Jewish Studies 25, no. 2 (2007): 4-23.

Ozick 2002 - Ozick, Synthia. Introduction to The Complete Works of Isaac Babel, by Isaac Babel, 13-18. New York; London: W.W. Norton, 2002.

Ozick 2010 - Ozick, Synthia. Putermesser i moskovskaia rodstvennitsa [Puttermesser and a Moscow Relative]. Moscow: Tekst Publ.; Knizhniki Publ., 2010. (In Russ.)

Ozick 2012 - Ozick, Synthia. Shal' [The Shawl]. Moscow: Tekst Publ.; Knizhniki Publ., 2012. (In Russ.)

Paley 2012 - Paley, Grace. Mechty na mertvom iazyke [Dreamer in a Dead Language]. Moscow: Tekst Publ.; Knizhniki Publ., 2012. (In Russ.)

Potok 2013 - Potok, Chaim. Izbrannik [The Chosen]. Moscow: Tekst Publ.; Knizhniki Publ., 2013. (In Russ.)

Roth 1994 - Roth, Philip. Bolezn' Portnogo. Professor zhelaniia. Proshchai, Kolambus [Portnoy's Complaint. The Professor of Desire. Goodbye, Columbus]. Vilnius: Polina Publ., 1994. (In Russ.)

Roth 2002 - Roth, Philip. Moia muzhskaia Pravda [My Life as A Man]. St. Petersburg: Limbus Press Publ., 2002. (In Russ.)

Roth 2001 - Roth, Philip. Sluchai Portnogo [Portnoy's Complaint]. St. Petersburg: Limbus Press Publ., 2001. (In Russ.) 
Shteyngart 2007 - Shteyngart, Gary. Absurdistan [Absurdistan]. Moscow: Amphora Publ., 2007. (In Russ.)

Varvogli 2001 - Varvogli, Aliki. The World that is the Book. Paul Auster's Fiction. Liverpool: Liverpool University Press, 2001.

Vol'tskaia 2012 — Vol'tskaia, Tat'iana. "Kniga "Bumazhnye mosty"” ["The Book 'Paper Bridges"']. Radio Svoboda (website), June 21, 2012. https://www. svoboda.org/a/24622403.html (In Russ.)

Wisse 2008 - Wisse, Ruth R. Sovremennyi evreiskii literaturnyi kanon. Puteshestvie po iazykam i stranam. [The Modern Jewish Canon: A Journey Through Language and Culture.] Moscow: Mosty kul'tury Publ., 2008. (In Russ.)

Zverev 2002 - Zverev, Aleksei M. "Triumf ochkarika" ["The Bespectacled Man's Triumph”]. Lekhaim 123, no. 7 (2002). https://lechaim.ru/ARHIV/123/n2.htm (In Russ.)

(c) 2021, О.Б. Карасик-Апдайк

Дата поступления в редакиию: 07.12.2020

Дата одобрения реиензентами: 20.01.2021

Дата публикаиии: 25.05.2021
(C) 2021, Olga B. Karasik-Updike

Received: 7 Dec. 2020

Approved after reviewing: 20 Jan. 2021

Date of publication: 25 May 2021 